\title{
Index to Volume 10
}

ADAMS, $\mathrm{S}$ Trees and amenable equivalence relations, 1

Aharonov, D and Elias, U Invariant curves around a parabolic fixed point at infinity, 209

Aharonov, D AND Elias, $U$ Parabolic fixed points, invariant curves and action-angle variables, 231

ANGENENT, S B Monotone recurrence relations, their Birkhoff orbits and topological entropy, 15

ASHLEY, J Marker automorphisms of the one-sided $d$-shift, 247

ASHLEY, J Bounded-to-1 factors of an almost aperiodic shift of finite type are 1-to-1 almost everywhere factors also, 615

AsSANı, I Minımal convergence on $L^{p}$ spaces, 411

BANGERT, V Minımal geodesics, 263

BEDFORD, T AND URBANSKI, $M$ The box and Hausdorff dimension of self-affine sets, 627

Bellow, A, Jones, R AND ROSENBlATt, J Convergence for moving averages, 43

Beloqui, J AND PaCifico, M J Quasi-transversal saddle-node bifurcation on surfaces, 63

Boyarsky, A See Byers, W, Gora, P AND Boyarsky, A, 645

Boyle, M AND TunCEL, S Regular isomorphism of Markov chains is almost topological, 89

Boyle, M , Franks, J AND Kitchens, B Automorphisms of one-sided subshifts of finite type, 421

Byers, W, Gora, P AND BoyARSKy, A Maximal absolutely contınuous invanant measures for piecewise linear Markov transformations, 465

CUTLER, C D Connectıng ergodicity and dimension in dynamical systems, 451

Elias, U See Aharonov, D and Elias, U, 209

Elias, U See Aharonov, D and Elias, U, 231

ELLIS, D B Suspensions of topological transformation groups, 101

FATHi, A Homotopical stability of pseudo-Anosov diffeomorphisms, 287

FERES, R AND KATOK, A Anosov flows with smooth foliations and rigidity of geodesic flows on three-dimensional manifolds of negative curvature, 657

FieldSTEEl, A AND Rudolph, D J Stability of $m$-equivalence to the weak Pinsker property, 119

FONTICH, E AND Simo, C The splitting of separatrices for analytıc diffeomorphisms, 295

FON IICH, E AND SIMO, C Invariant manıfolds for near identity differentıable maps and splittıng of separatrices, 319

Franks, J See Boyle, M, Franks, J and Kitc hens, B, 421

GLASNER, E A topological version of a theorem of Veech and almost simple fiows, 463

Gora, P See Byers, W, Gora, P AND BoyARSKy, A, 645

GuivarCH, Y Produits de matrices aléatoıres et applıcatıons aux propriétés géometrıques des sousgroupes du groupe linéaıre, 483

HAYDN, N T A Meromorphic extension of the zeta function for Axiom A flows, 347

HUMKe, P D AND LACZKovich, M Approximations of continuous functions by squares, 361

HURLEY, M Attractors in cellular automata, 131

HURLEY, M Ergodic aspects of cellular automata, 671

Jones, R See Bellow A, Jones, R and Rosenblatt, J, 43

DEL JUNCO, A Bernoullı shifts of the same entropy are finitarily and unilaterally isomorphıc, 687

KATOK, S Approxımate solutions of cohomological equatıons associated with some Anosov flows, 367

KATOK, A See FERES, R AND KaTOK, A, 657

KEller, G Exponents, attractors and Hopf decompositions for interval maps, 717

Kim, K H AND Roush, F W An algorithm for sofic shift equivalence, 381 
KING, J A map with topological minimal self-joinıngs in the sense of del Junco, 745

Kitchens, B See Boyle, M, Franks, J AND Kitchens, B, 421

Laczkovich, M See Humke, P D and Laczkovich, M , 361

LEMANCZYK, M AND MENTZEN, $M$ K Compact subgroups in the centralizer of natural factors of an ergodic group extension of a rotation determine all factors, 763

LESIGNE, $E$ Un théorème de disjonctıon de systèmes dynamiques et une généralısatıon du théorème ergodique de Wiener-Wintner, 513

LEVI, M KAM theory for particles in periodic potentıals, 777

MARDESIC, P The number of limit cycles of polynomial deformations of a Hamiltonian vector field, 523

Martens, M, van Strien, S, de Melo, W and Mendes, P On Cherry flows, 531

MARTIN-REYES, F J AND DE LA TORRE, A On the almost everywhere convergence of the ergodic averages, 141

MASUR, $H$ The growth rate of trajectories of a quadratic differential, 151

MAYER, J C An explosion point for the set of endpoints of the Julia set of $\lambda$ exp (z), 177

de Melo, W See Martens, M, van Strien, S, de Melo, W and Mendes, P, 531

Mendes, $P$ See Martens, M, van Strien, S, de Melo, W and Mendes, P, 531

Mentzen, M K See Lemanczyk, M and Mentzen, M K, 763

MOECKEL, $R$ Generic bifurcations of the twist coefficient, 185

MOSHER, L Correction to 'Equivariant spectral composition for flows with a 2-action', 787

MrozeK, $M$ Open index pairs, the fixed point index and rationality of zeta functions, 555

Pacifico, M J See Beloqui, J and Pacifico, M J, 63

PutNam, I F On the topological stable rank of certain transformation group $C^{*}$-algebras, 197

Rosenblatt, J See Bellow, A, Jones, R and Rosenblatt, J , 43

Roush, F W See KIM, K H AND Roush, F W, 381

RUDOLPH, D J $\times 2$ and $\times 3$ invanant measures and entropy, 395

Rudolph, D J See Fieldsteel, A ANd Rudolph, D J, 119

RYCHLıK, M R Lorenz attractors through Šl'nıkov-type bıfurcatıon Part I, 793

Simo, C See Fontich, E And Simo, C, 295

Simó, C See Fontich, E and Simo, C, 319

SMillie, J The entropy of polynomial diffeomorphisms of $C^{2}, 823$

van Strien, S J See Martens, M, van Strien, S, de Melo, W and Mendes, P, 531

de la Torre, See Martin-Reyes, F J and de la Torre, A, 141

Tuncel, $S$ See Boyle, $M$ and Tuncel, $S, 89$

URBANSKI, M See BedFord, T AND URBANSKI, M, 627

WANG, $X$ The $C^{*}$-algebras of Morse-Smale flows on two-manifolds, 565

Withers, WM D Differentiability with respect to parameters of average values in probabilistic contractıng dynamical systems, 599

BOOK REVIEWS 407,611 